This paper has been retracted. A Retraction notice was published on 20 January 2016, in Proceedings of the 1st International Electronic Conference on Remote Sensing, 22 June-5 July 2015; Sciforum Electronic Conference Series, Vol. 1, 2016 , d017; doi:10.3390/ecrs-1-d017

\title{
Mapping of Land Use and Land Cover on Brazil
}

\author{
1 Brazilian Institute of Geography and Statistics; rodrigo.macedo@ibge.gov.br \\ 2 National Institute of Space Research; jroberto@dsr.inpe.br \\ 3 Brazilian Institute of Geography and Statistics; fernando.dias@ibge.gov.br \\ 4 Brazilian Institute of Geography and Statistics; mauricio.moreira@ibge.gov.br \\ 5 Brazilian Institute of Geography and Statistics; luiz.jacintho@ibge.gov.br \\ 6 Brazilian Institute of Geography and Statistics; eloisa.domingues@ibge.gov.br
}

Rodrigo de Campos Macedo ${ }^{1}$ *, João Roberto dos Santos ${ }^{2}$, Fernando Peres Dias ${ }^{3}$, Maurício Zacharias Moreira ${ }^{4}$, Luiz Roberto de Campos Jacintho ${ }^{5}$ and Eloisa Domingues ${ }^{6}$

* Author to whom correspondence should be addressed; E-Mail: rodrigo.macedo@ibge.gov.br; Rua Almirante Lamego, 747 apto. 1107 - CEP 88015-600 - Centro - Florianópolis/SC - Brazil. Tel.: $+55-48-9647-6746$.

Published: 22 June 2015

Abstract: The monitoring of land cover and land use changes is justified by the growing need for management and monitoring of global changes, as recommended by UNCED-92 and subsequent conferences in Johannesburg (Rio +10$)$ and Rio de Janeiro (Rio + 20). Based on an infernational methodological framework, which identifies changes in terrestrial ecosystems, the main purpose of this work is to monitor changes in land cover and land use for all the brazilian territory, at regular intervals, by the systematic mapping and the use of a territorial grid for statistical purposes. The methodology involves five stages of work: pre-processing; classification; edition; validation; and map algebra. A preliminary analysis allowed the observation of some changes in the study period. There was significant loss of forest cover. However, areas of grasslands, including savannas, scrublands and pioneer formations, suffered proportionately the greatest reduction. Some changes can be highlighted, such as the significant growth in agriculture and pastures in 
northern Mato Grosso, the increase of pastures in eastern Pará, east of Acre and Rondônia, and the expansion of planted forests in the south region, especially in Santa Catarina and Paraná.

Keywords: Land use and cover change (LUCC); Remote Sensing; Map Algebra; Change Detection.

\section{Introduction}

Territorial dynamics studies help to generate an important support tool to decision-making and management actions. They allow monitoring of changes in forms of employment and organization of space, enabling the detection of land use and cover change (LUCC) over a giyen period [1]. They also provide support for studies of environmental impacts on ecosystems [2].

The LUCC detection is justified by the growing need for management and monitoring of global changes, as recommended in UNCED-92 in the subsequent conference in Johannesburg (Rio +10$)$ and Rio de Janeiro (Rio +20 ). More recently, with the Objectives of Sustainable Development of the United Nations, which called for the creation a network solutions with targets and indicators to reduce social inequalities and promote social inclusion, poverty eradication, the promotion of equality, protection environmental, valuing education and health and the effective provision of non-fossil energy sources.

Based on an international methodological framework that identifies the changes in terrestrial ecosystems, this proposal is intended to subsidize the calculations of physical accounts of LUCC, which, in turn, will be used in studies aimed at economic valuation of environmental changes. It can also be inserted in the attempt of the United Nations Food and Agriculture Organization (FAO) to establish a worldwide system of land cover classification in support of environmental accounting [3; 4].

This work focuses on the LUCC monitoring of Brazil, at regular intervals, from the systematic land use and land cover mapping. In this context the following specific objectives were established:

Map the land use and the land cover of the brazilian territory for the years 2000 and 2010;

- Map the LUCC of the brazilian territory, from the difference between the land use and land cover maps. 


\section{Material \& Methods}

\subsection{Data}

- Cartographic maps 1:250.000 (BC250-IBGE) - roads and rivers [5];

- Agricultural Calendar - Images selection;

- Agricultural research, such as Systematic Survey of Agricultural Production [6], Municipal Agricultural Research [7], Municipal Livestock Research [8] and Agricultural Census [9];

- Pluviometric data - Images selection;

- Deforestation polygons, from PRODES Project [10]; and classes of land cover / land use, from Terraclass Project

- MOD13A1 product, from the MODIS sensor (Moderate Resolution Imaging Spectroradiometer), in the red, near-infrared and mid-infrared spectral regions; and NDVI (Normalized Difference Vegetation Index) - primary data [12]

- Images from the TM (Thematic Mapper) and ETM + (Enhanced Thematic Mapper Plus) sensors (Landsat satellite series) - checks;

- Temporal Series - developed by the Remote Sensing Laboratory Applied to Agriculture and Forest (LARF-INPE), available at https://www.dsr.inpe.br/laf/series, using the EVI (Enhanced Vegetation Index) - checks.

\subsection{Softwares}

- Google Earth version 7.0 - checks;

- $\quad$ MRT (Modis Reprojection Tools) - conversions [13];

- Spring version 5.1.7-production [14].

\subsection{Methods}

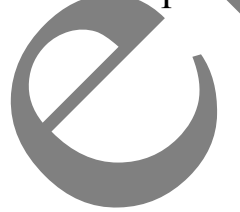

The procedures involve five work steps: i) pre-processing; ii) interpretation and image classification; iii) matrix editing and integration; iv) validation and; v) map algebra. 


\section{i) Pre-processing}

The pre-processing includes acquisition and conversion of MOD13 product, including the spectral bands in the regions of red, near infrared, medium infrared and the NDVI index with spatial resolution of $250 \mathrm{~m}$.

The acquisition is carried out through the United States Geological Survey (USGS). In the selection of the images dates in order to avoid scenes with high percentage of clouds, are subject to the rainfall characteristics of each region and also the national agricultural calendar, aiming to know the types of crops contained in selected images, facilitating the spectral identification of these extensive agricultural stands. The NDVI images were selected by the agricultural calendar and also the rainfall. Thus, we used three different dates of images of the same year, aiming to discriminate annual crops of other types of land cover [15]. The MODIS images are available originally in $h d f$ format and converted to tiff format [13]. It held the histogram enhancement (contrast adjustments) and some colorful compositions in order to facilitate the interpretation on screen.

\section{ii) Interpretation and image classification}

The land use and land cover classes were elected from the compatibility with the Land Use and Land Cover Classification System [16] with the System of Environmental-Economic Accounting (SEEA) and the Land Cover Functional Unit (LCFU) [17]

The images are segmented (Growing Region) and undergo a unsupervised classification (ISOSEG). Then, it made the association between the classes generated by this classification and the previously defined classes to work. This association is performed through image interpretation, using various support data, such as other images (Landsat and Google Earth), agricultural calendars, agricultural research data, time series (EVI) and other surveys.

\section{iii) Matrix editing and integration}

The matrix editing is a non-automated process, performed in order to correct any imperfections generated by unsupervised classification and by the association process. At this stage they are also used other information, such as thematic maps, surveys, medium and high spatial resolution images.

In the next phase it is incorporated data from the brazilian agricultural census [5], spatialized and converted into shape format. In rural census sectors is checked for representative areas of pasture, considering the seale used. They are also incorporated data generated by various other institutions, such as those specific to the PRODES and TerraClass projects, referring to the regular annual survey of deforested areas in the Brazilian Amazon $[10 ; 11]$.

The hydrographic mapping obtained in BC250 [5] are incorporated. After editions and integrations, carried out a technical review, including identification of inconsistencies, especially at the edges and borders. In this review are eliminated polygons with area less than 10 pixels and realized geometric adjustments. 


\section{iv) Validation}

In order to verify the accuracy of classifications, were conducted field campaigns in representative areas. Because of the large capillary present in the IBGE, with over 550 agencies throughout Brazil, there is considerable representation of field coordinates, extensively covering the brazilian territory.

The validation procedure consists of comparing the mapped class and the coordinated field, obtained with a description of the local landscape. We used the Kappa index for this assessment [18; 19].

v) Map algebra

The LUCC maps are generated from the overlay and crosstab of thematic maps for the 2000-2010 periods. These crosses are performed in raster format, thus generating transition matrices $[20 ; 21,22]$.

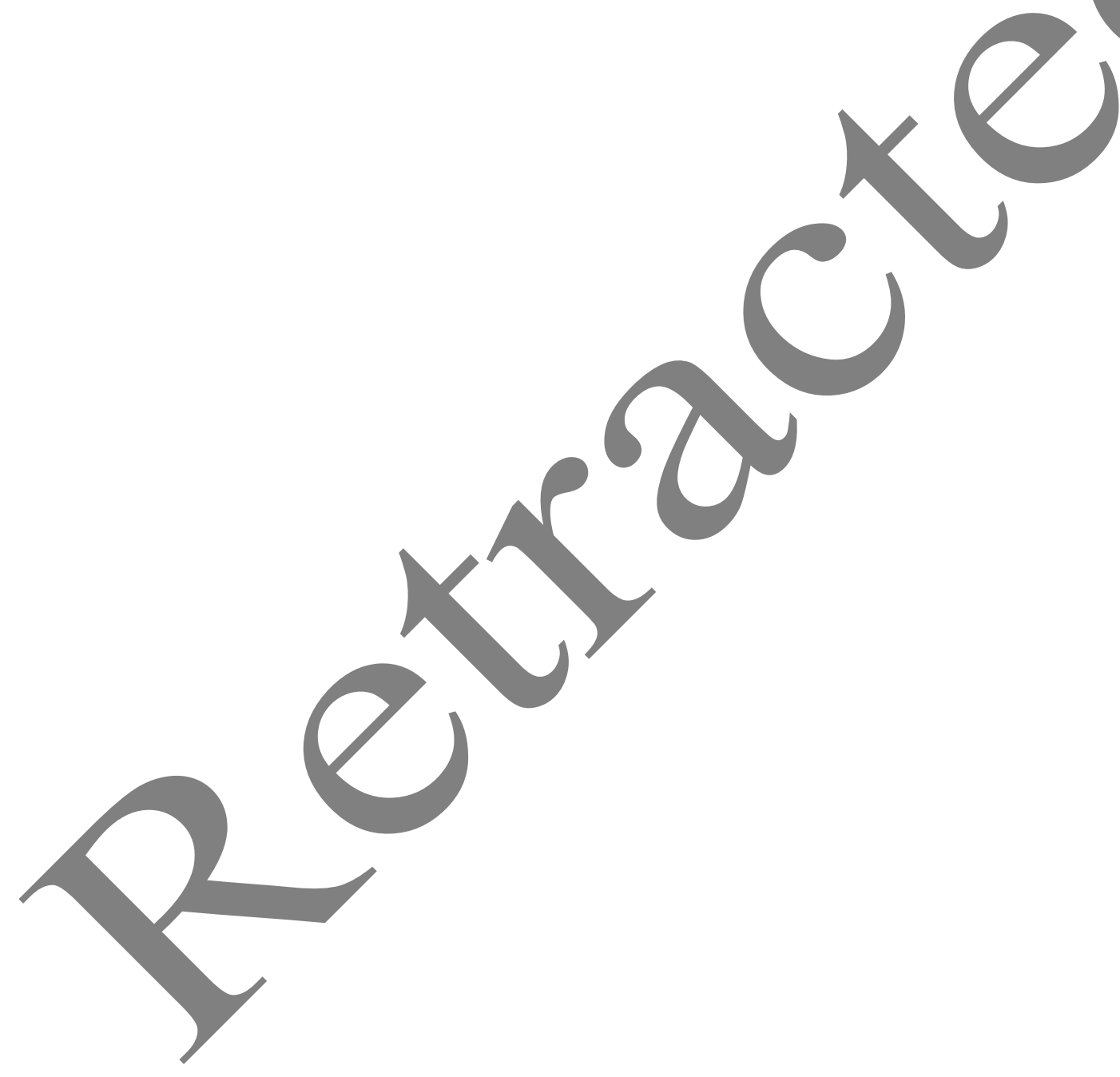




\section{Results and Discussion}

Figures 1-2 express the variation on the land use and land cover on Brazil, for the period 2000-2010 (Figure 1) and 2010-2012 (Figure 2). It's important to express that this methodology is not appropriate to measure the flooding and urban expansion. For this, there's no changes related to water and the artificial areas ${ }^{1}$ has a very small increase in the both periods.

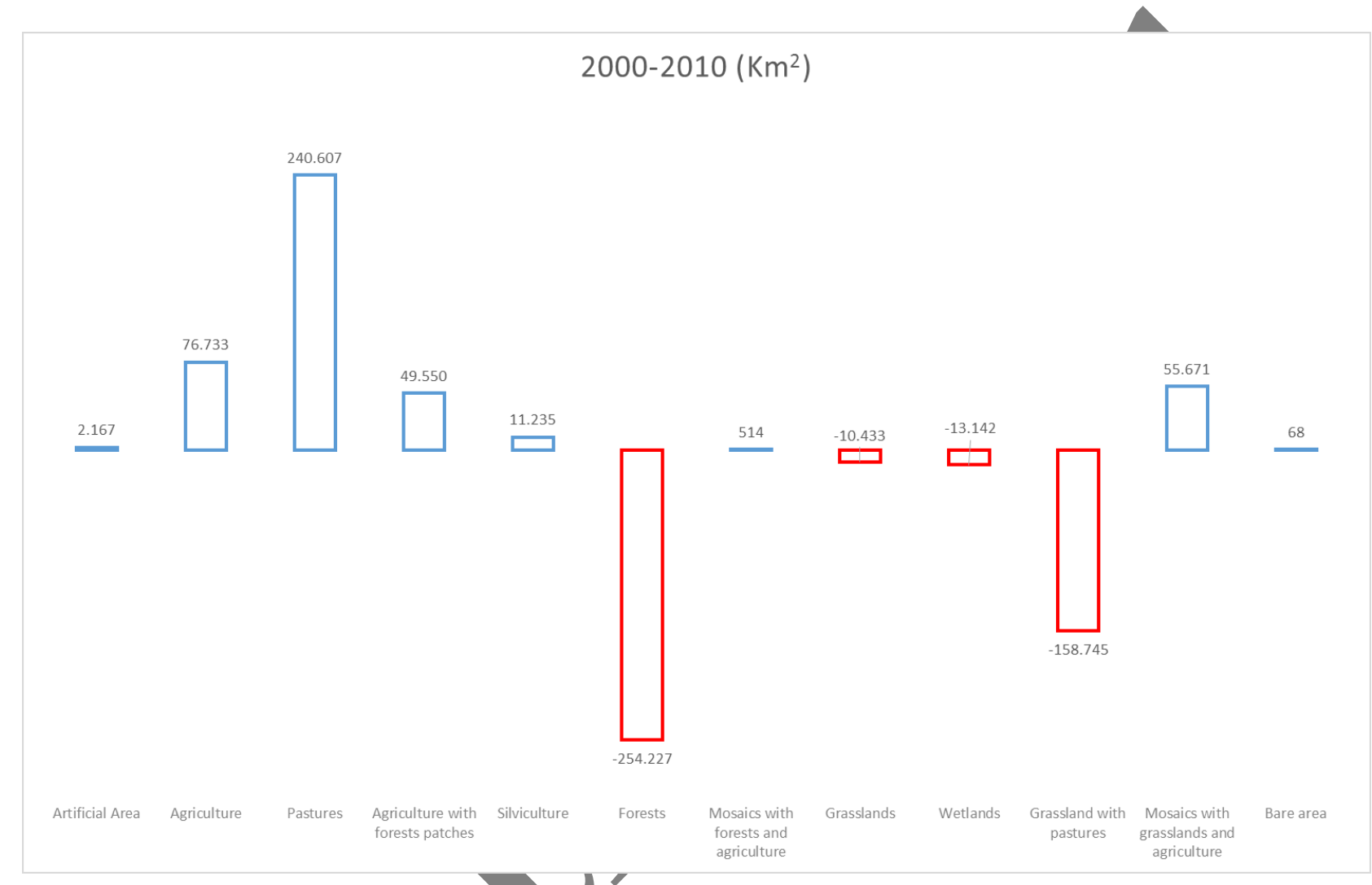

Figure 1. Land use and cover changes on Brazil - 2000 to 2010

Between the years 2000 and 2010, forests and grassland (savannas, scrublands and pioneer formations) suffering the biggest reductions. These classes was occupied by livestock cattle (in forests) and agriculture (in grasslands).

\footnotetext{
${ }^{1}$ Cities, roads and mines.
} 


\section{$2010-2012\left(\mathrm{Km}^{2}\right)$}

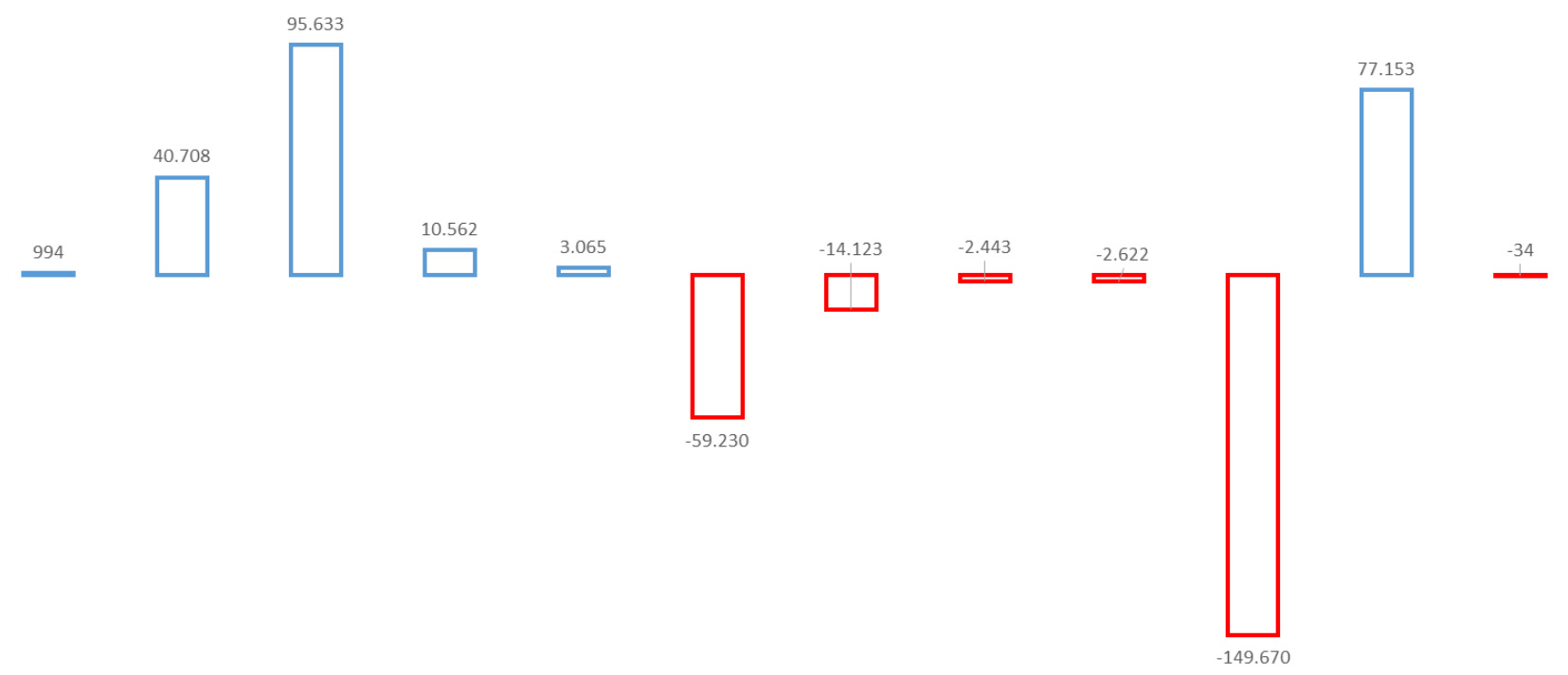

Figure 2. Land use and cover changes on Brazil - 2010 to 2012

Between the years 2010 and 2012, there was a reduction on the deforestation and a strong direction to expand the agriculture on savannah.

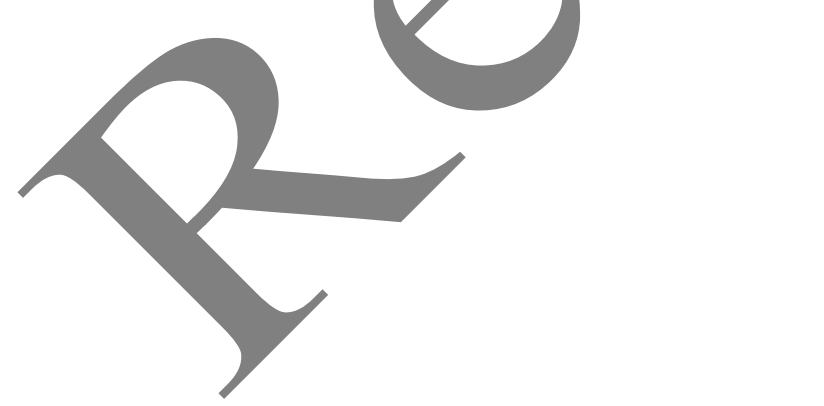




\section{Conclusions}

In proportional terms, both forests as grasslands have been converted to agricultural land, pastures and mosaics between native and disturbed vegetation types. In Brazil, the changes that deserve greater emphasis are: the steady advance of agriculture and pastures in northern of Mato Grosso state, the increase in pasture in the eastern states of Pará, Acre and Rondonia, and the expansion of silviculture in the south of Brazil.

There are indications that the agriculture will continue to expand, but prioritizing areas with degraded pastures. Regards to livestock, are increasingly present policies that disincentive the advance of the "cattle frontier", such as soy moratorium. In addition, there is improvement of intensive farming to meat and milk production.

We recommend more detailed investigations, either in specific areas or in certain LUCC processes, such as selective logging, very difficult to be measured by the methodology presented.

\section{Conflicts of Interest}

The authors declare no conflict of interest.

\section{References and Notes}

[1] FREITAS, M. W. D.; SANTOS, J. R.; ALVES, D. S. Land-use and land-cover change processes in the Upper Uruguay Basin: linking environmental and socioeconomic variables. Landscape Ecology, v. 28, p. 311-327, 2013.

[2] R. C.; ALMEIDA, C. M.; SANTOS, J. R.; RUDORFF, B. F. T.; SOARES-FILHO, B. S.; RODRIGUES, H. O; JÚNIOR, W. C. S. Economic impact assessment of silting-up and erosion processes: how spatial dynamic models coupled with environmental valuation models can foster sustainable practices in sugarcane farming. In: Eleanore Webb (Org.). Sugarcane: Production, Consumption and Agrieultural Management Systems. [s.n.] . NovaScience Ed. 2014. p. 532550. ISBN: 978-1-63321-699-0. Disponível em: http://urlib.net/8JMKD3MGP5W34M/3GHD6L5 .

[3] JAFFRAIN, G.; Proposal of Land Cover System Classification for Ecosystem Accounting. Working document. Final report. European Topic Centre Spatial Information and Analysis. 2012.

[4] WEBER, J. L. Land cover classification in the revised SEEA: draft for discussion. Copenhagen: European Environment Agency, 2010. Disponível em: http://eea.eionet.europa.eu/Public/irc/eionetcircle/leac/library?l=/classification_october20/EN_1.0_\&a=d. Acesso em: 2011.

[5] IBGE - Instituto Brasileiro de Geografia e Estatística. Base cartográfica contínua 1:250.000. Rio de Janeiro, 2011. 
[6] IBGE - Instituto Brasileiro de Geografia e Estatística. Levantamento Sistemático da Produção Agropecuária. Diretoria de Pesquisas Estatísticas. Coordenação de Agropecuária. Gerência de Agricultura. 2012.

[7] IBGE - Instituto Brasileiro de Geografia e Estatística. Pesquisa agrícola municipal. Rio de Janeiro: Diretoria de Pesquisas Estatísticas. Coordenação de Agropecuária. Gerência de Agricultura, 2012.

[8] IBGE - Instituto Brasileiro de Geografia e Estatística. Pesquisa pecuária municipal. Rio de Janeiro: Diretoria de Pesquisas Estatísticas. Coordenação de Agropecuária. Gerência de Agricultura, 2012.

[9] IBGE - Instituto Brasileiro de Geografia e Estatística. Censo agropecuário. Coordenação de Agropecuária. Gerência de Agricultura. 2008.

[10] INPE - Instituto Nacional de Pesquisas Espaciais. Metodologia para o Cálculo da Taxa Anual de Desmatamento na Amazônia Legal - PRODES. 2006.

[11] INPE - Instituto Nacional de Pesquisas Espaciais. Projeto TerraClass. 2010.

[12] RUDORFF, B. F. T.; SHIMABUKURO, Y. E.; CEBAlloS, J. C. (Coord.). Sensor MOdIS e suas Aplicações Ambientais no Brasil. 1.ed. São José dos Campos: Ed. Parêntese, 2007. 425p.

[13] TAAHERI, A.; COHEN, A. HDF-EOS to GeoTIFF Conversion Tool. Stand-alone User's Guide. Disponível em: ftp://edhs1.gsfc.nasa.gov/edhs/HEG Tool/Version2.11/516eed001 HEG UsersGuide v2.11.pdf Acesso em: 2013.

[14] INPE - Instituto Nacional de Pesquisas Espaciais. Disponível em: http://www.dpi.inpe.br/spring [15] MACEDO, R. C.; ALMEIDA, C. M.; SANTOS, J. R.; RUDORFF, B. F. T. Modelagem dinâmica espacial das alterações de cobertura e uso da terra relacionadas à expansão canavieira. In: Boletim de Ciências Geodésicas, v. 19, n. 2, p. 313-337, abr.-jun. 2013. doi: <10.1590/S198221702013000200009>. Disponível em: <http://urlib.net/J8LNKAN8RW/3E7UNNS>.

[16] IBGE - Instituto Brasileiro de Geografia e Estatística. Manual técnico de uso da terra. 3.ed. Manuais técnicos em geociências, n.7. Rio de Janeiro, 2013. 170p.

[17] SEEA - System of Enyironmental-Economic Accounting. Central Framework. White Cover Publication: 2012.306p.

[18] MATHER, P. M. Computer processing of remotely-sensed images: an introduction. 3. ed. England: John Wiley \& Sons, 2004. 326 p.

[19] JENSEN, J. R. Introductory digital image processing: a remote sensing perspective. 3. ed. New Jersey: Pearson Prentice Hall, 2005. 528 p.

[20] MACEDO, R. C. Modelagem dinâmica espacial da expansão da agricultura em Campos Novos SC. In: XVI Simpósio Brasileiro de Sensoriamento Remoto, (SBSR), 2013, Foz do Iguaçu - PR. Anais... São José dos Campos - SP: INPE, 2013. p. 6355-6362. ISBN 978-85-17-00066-9 (Internet), 978-85-17-00065-2 (DVD). Disponível em: http://urlib.net/3ERPFQRTRW34M/3E7G6HU .

[21] MACEDO, R. C. Modelagem dinâmica espacial e valoração das alterações de cobertura e uso da terra relacionadas à expansão canavieira. 2013. 266 p. (sid.inpe.br/mtcm19/2013/09.06.18.13-TDI). Tese (Doutorado em Sensoriamento Remoto) - Instituto Nacional 
de Pesquisas Espaciais (INPE), São José dos Campos - SP, 2013. Disponível em: http://urlib.net/8JMKD3MGP7W/3EPSPRS .

[22] BAN, Y.; GONG, P.; GIRI, C. Global land cover mapping using Earth observation satellite data: Recent progresses and challenges. ISPRS Journal of Photogrammetry and Remote Sensing, v. 103. 2015. 6p.

(C) 2015 by the authors; licensee MDPI, Basel, Switzerland. This article is an open access article distributed under the terms and conditions of the Creative Commons Attribution license (http://creativecommons.org/licenses/by/4.0/).

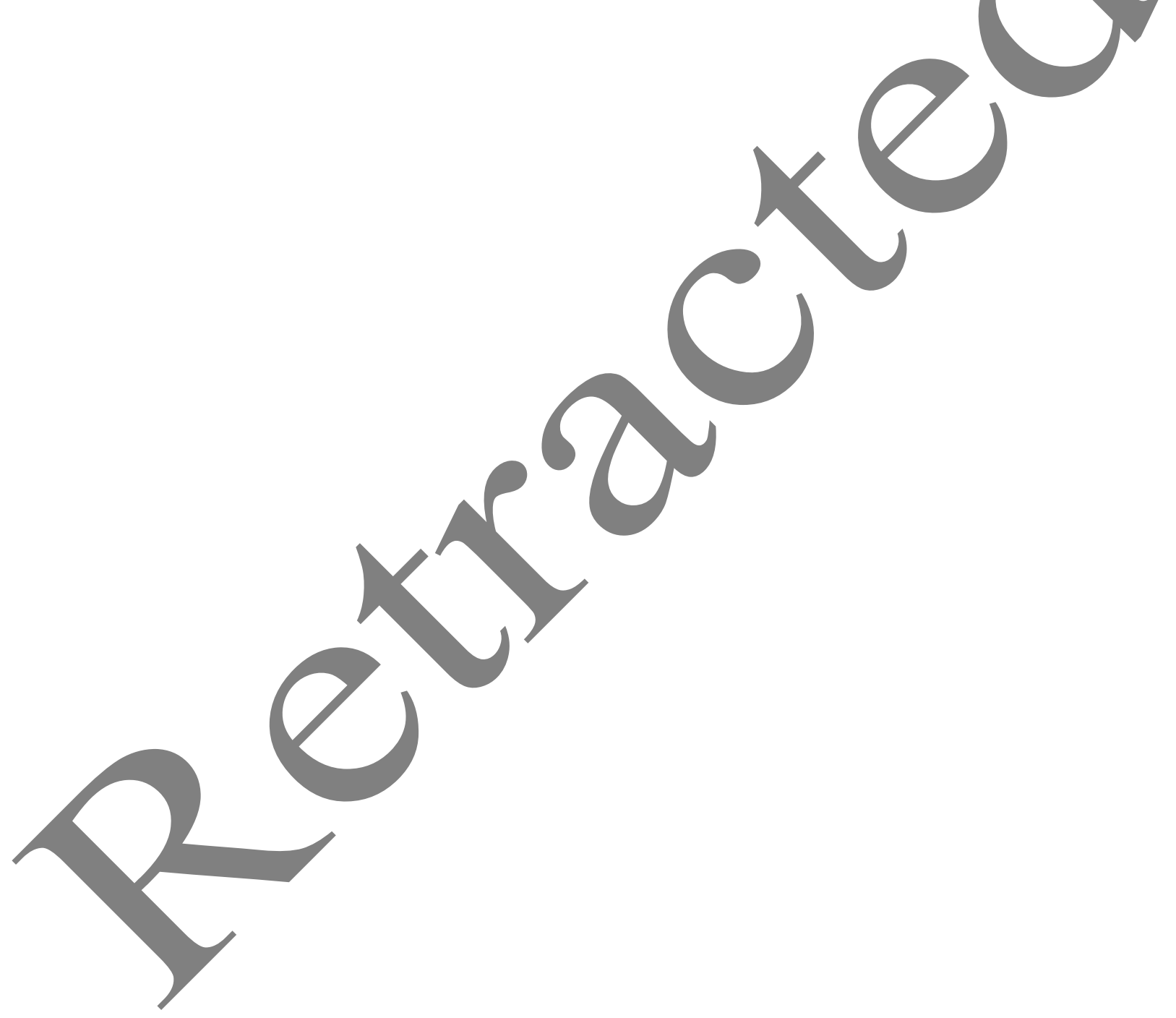

